\title{
Quality Characteristics of Chicken Meat Cutlets Incorporated with Finger Millet (Eleusine coracana) Flour
}

\author{
Martina Gamit ${ }^{1 *}$, Swati Gupta ${ }^{1}$ and C.V. Savalia ${ }^{2}$ \\ ${ }^{1}$ Department of Livestock Products Technology, Vanbandhu College of Veterinary Science and Animal Husbandry, Navsari \\ Agricultural University, Navsari, Gujarat, INDIA \\ ${ }^{2}$ Department of Veterinary Public Health and Epidemiology, Vanbandhu College of Veterinary Science and Animal Husbandry, \\ Navsari Agricultural University, Navsari, Gujarat, INDIA \\ "Corresponding author: M Gamit; E-mail: drmgamit@gmail.com
}

Received: 15 Nov., 2019

Revised: 07 Jan., 2020

Accepted: 11 Jan., 2020

\begin{abstract}
In view of continuously growing demand of snacks foods worldwide due to rapid changing lifestyle, industrialization and urbanization, the present study was conducted to standardize the incorporation level of finger millet flour for preparation of chicken meat cutlets. Chicken meat cutlets were prepared with different levels of finger millet flour viz. 5, 10, and 15\%, and different levels by replacing the lean meat in chicken cutlets formulation. The optimum (mention) level of finger millet was standardized as $5 \%$ for incorporation in chicken meat cutlets. Crude fiber and calcium content of chicken cutlets prepared with finger millet flour was significantly higher as compared to control thereby depicting marked improvement in the desirable food trait with health benefits. The product yield of chicken meat cutlets with optimized level of finger millet flour was significantly higher as compared to control. It did not show significant effect on any of the sensory parameters. Storage stability of aerobically packaged chicken meat cutlets with optimum level (mention level) of finger millet flour along with control was further evaluated during refrigerated storage $\left(4 \pm 1^{\circ} \mathrm{C}\right)$ at regular intervals of $0,3,6$ and 9 days with respect to physico-chemical, microbiological and sensory characteristics. Chicken meat cutlets could be stored safely in aerobic packaging for 6 days at refrigeration condition $\left(4 \pm 1^{\circ} \mathrm{C}\right)$.
\end{abstract}

Keywords: Finger millet flour, Chicken meat cutlets, Physico-chemical attributes, Sensory characteristics

Increasing focus on health and nutrition has led to growing consumer demand for healthier food products. The readyto-eat / ready-to-prepare (RTE/RTP) food provides suitable option for consumers in today's busy life style (Singh et al., 2014). Meat cutlets are ready to eat convenient meat products widely used in the breakfast throughout the world. Cutlets are flat croquette of minced meat, flour, pulse, nuts, shredded potato, condiments, spices and often coated with rusk crumbs. Development of fast food sector is mainly contributed to the rapid urbanization and change in the food habits. Finger millet (Eleusine coracana) 'Ragi' is one of the most popular millet in India. It is vital food grain of rural population belonging to small farmers. Ragi is rich source of dietary fiber, protein, mineral and low in fat (Singh and Raghuvanshi, 2012). It is suitable for gastric patient because easy to digest without creating much acid. Polyphenols compounds in finger millet, possess other health benefits such as antimicrobial, anti-inflammatory, antiviral, anticancer, antiplatelet aggregation and inhibitory activities on cataract formation (Viswanath et al., 2009). It is healthier food for adolescent and pregnant women, growing children and osteoporosis condition. The consumption of finger millet flour helps in reducing the post prandial glucose level due to high fiber content as the fiber get digested very slowly. In meat and meat products dietary fiber are lacking for that longer period associated with various health disorders such as

How to cite this article: Gamit, M., Gupta, S. and Savalia, C.V. (2020) Quality characteristics of chicken meat cutlets incorporated with finger millet (Eleusine coracana) flour. J. Anim. Res., 10(1): 111-116. 
colon cancer, obesity and cardiovascular diseases. Thus the present study was undertaken to standardize and evaluate the incorporation level of finger millet (Eleusine coracana) flour for preparation of chicken meat cutlets.

\section{MATERIALS AND METHODS}

\section{Raw materials}

Broiler birds vencobb-400' were procured from Instructional Livestock Farm Complex of Vanbandhu Veterinary College, Navsari and slaughtered by using halal method. The dressed broiler carcasses were deboned by removing fat, tendons and connective tissue. The deboned meat was packaged in LDPE (low density polyethylene) bags and frozen at $-18 \pm 2{ }^{\circ} \mathrm{C}$ till use. The frozen deboned meat were drawn as per requirement and thawed overnight in a refrigerator $\left(4 \pm 1^{\circ} \mathrm{C}\right)$ andwere used for further study. Finger millet flour, spices, table salt (Tata Chemicals Ltd, Mumbai), sugar, condiments (onion, ginger and garlic), vegetable oil (Sunflower oil - Adani Wilmar Limited Company) and low density polyethylene (200 gauge) bags were purchased from local market of Navsari. All the chemicals used in the study were purchased from standard firms (Hi media). Condiments mix was prepared by peeling off onion, ginger and garlic, cutting in to small pieces and mixing it in mixer in the ratio of $4: 2: 1$.

\section{Methodology for preparation of chicken meat cutlets}

Frozen deboned chicken meat was cut into small pieces and minced in meat mincer (Model no. P-22, Ramon) using $6 \mathrm{~mm}$ plate for two times and used for preparation of cutlet. Chicken meat cutlets were prepared by slight modified method of Singh et al. (2014). Finger millet flour was incorporated at the levels of 5,10 and $15 \%$ by replacing the lean meat in chicken cutlets formulation.

\section{pH}

The $\mathrm{pH}$ of chicken meat cutlets was determining by method of Trout et al. (1992).

\section{Product yield}

The product yield was calculated as:

Product yield $(\%)=$

$$
\frac{\text { Weight of cooked chicken meat cutlet }}{\text { Weight of }} \times 100
$$

\section{Proximate composition}

Moisture, crude protein, crude fat, crude fiber, ash and calcium content of chicken meat cutlets were determined by standard procedure of Association of Office Chemist (AOAC, 1995).

\section{Free fatty acids}

The method described by Koniecko (1979) was followed for the estimation of free fatty acid.

\section{Thiobarbituric acid (TBA) value}

The method of Witte et al. (1970) with suitable modification was followed for thiobarbituric acid (TBA) value.

\section{Microbiological analysis}

Standard plate counts, Psychrophilic counts, Coliform counts and Yeast and mold counts were enumerated following the method described by American Public Health Association (APHA, 2001).

\section{Sensory evaluation}

Sensory evaluation panel consisting of seven members of the College of Veterinary Science and Animal Husbandry, Navsari participated in sensory evaluation. The chicken meat cutlets were evaluated for general appearance, flavour, juiciness, texture and overall acceptability (Keeton, 1983), using an 8-point descriptive scale, where 8 is extremely desirable and 1 is extremely undesirable. The panelists were seated in a room free of noise and odours and suitably illuminated. Plain water was provided for oral rinsing between the samples.

\section{STATISTICAL ANALYSIS}

The data obtained from each experiment was analyzed statistically for analysis of variance (ANOVA) and Duncan's multiple range test as per the methods described by Snedecor and Cochran (1994). Each experiment was repeated for five times and the samples were analysed in duplicate except for the sensory score.

\section{RESULTS AND DISCUSSION}

The mean values of the physico-chemical characteristics 
of chicken meat cutlets prepared with different levels of finger millet flour are presented in Table 1. The product yield of the chicken meat cutlets prepared with finger millet flour was significantly higher $(p<0.05)$ than control. Product yield of chicken meat cutlets prepared with $10 \%$ finger millet flour was comparable to 5 and $15 \%$ finger millet flour incorporation levels. The observations are in agreement with those of Das et al. (2015) who reported significantly higher cooking yield in chicken patties formulated with finger millet flour. The $\mathrm{pH}$ of chicken cutlets prepared with 10 and $15 \%$ levels of finger millet flour incorporation was significantly $(p<0.05)$ lower than that of control. Naveena et al. (2006) also reported significant decrease $(\mathrm{p}<0.05)$ in $\mathrm{pH}$ of chicken nuggets incorporated with finger millet flour, in contrary to this study. Moisture percentage of chicken meat cutlets prepared with $15 \%$ finger millet flour was significantly lower $(p<0.05)$ than control and other treatment products. The decrease in moisture percentage may be attributed to less moisture content in finger millet flour as compared to that in chicken meat. The observations are in accordance with those of earlier workers, who prepared different types of meat products with addition of different flours (Gupta et al., 2015). Protein and fat percentage at all three levels of finger millet flour incorporation was significantly lower $(p<0.05)$ than that of control chicken meat cutlets. The reduction in protein and fat percentage of chicken cutlets may be attributed to lower protein and fat content of finger millet flour as compared to that in chicken meat. The findings are in accordance with Chatli et al. (2015) who also reported significant decrease $(p<0.05)$ in the protein and fat content of emu meat nuggets formulated with finger millet flour incorporation. Ash and crude fiber of chicken meat cutlets prepared with finger millet flour was significantly $(p<0.01)$ higher than control. It might be due to higher mineral and crude fiber content in finger millet flour than chicken meat. This result is in accordance with those of Das et al. (2013) who also reported significance difference in ash content of chicken patties. Calcium content of the chicken cutlets prepared with finger millet flour was significantly $(p<0.05)$ higher than control. Among treatments, calcium content also increased significantly with increased level of finger millet flour. This might be attributed to higher calcium in finger millet flour as compared to chicken meat. The findings are in accordance with that of Kumar et al. (2015) who also reported significance increase in calcium and crude fiber content of goat meat patties incorporated with finger millet flour.

Table 1: Effect of different levels of finger millet flour on physico-chemical characteristics of chicken meat cutlets

\begin{tabular}{lllll}
\hline Parameters & T1 & T2 & T3 & T4 \\
\hline Product yield & $72.95 \pm$ & $75.95 \pm$ & $78.63 \pm$ & $80.86 \pm$ \\
$(\%)$ & $0.38^{\mathrm{a}}$ & $0.79^{\mathrm{b}}$ & $1.29^{\mathrm{bc}}$ & $1.02^{\mathrm{c}}$ \\
$\mathrm{pH}$ & $6.25 \pm$ & $6.23 \pm$ & $6.22 \pm$ & $6.19 \pm$ \\
& $0.009^{\mathrm{b}}$ & $0.01^{\mathrm{ab}}$ & $0.01^{\mathrm{a}}$ & $0.02^{\mathrm{a}}$ \\
Moisture (\%) & $52.71 \pm$ & $50.72 \pm$ & $49.97 \pm$ & $46.48 \pm$ \\
& $0.47^{\mathrm{c}}$ & $0.67^{\mathrm{b}}$ & $0.56^{\mathrm{b}}$ & $0.94^{\mathrm{a}}$ \\
Protein (\%) & $21.35 \pm$ & $19.21 \pm$ & $19.10 \pm$ & $18.76 \pm$ \\
& $0.55^{\mathrm{b}}$ & $0.44^{\mathrm{a}}$ & $0.53^{\mathrm{a}}$ & $0.45^{\mathrm{a}}$ \\
Fat (\%) & $13.92 \pm$ & $12.82 \pm$ & $11.26 \pm$ & $9.04 \pm$ \\
& $0.28^{\mathrm{d}}$ & $0.39^{\mathrm{c}}$ & $0.26^{\mathrm{b}}$ & $0.33^{\mathrm{a}}$ \\
Ash (\%) & $3.72 \pm$ & $3.86 \pm$ & $3.88 \pm$ & $3.93 \pm$ \\
& $0.41^{\mathrm{a}}$ & $0.44^{\mathrm{b}}$ & $0.06^{\mathrm{b}}$ & $0.05^{\mathrm{b}}$ \\
Crude fiber (\%) & $0.85 \pm$ & $1.07 \pm$ & $1.29 \pm$ & $1.76 \pm$ \\
& $0.007^{\mathrm{a}}$ & $0.015^{\mathrm{b}}$ & $0.009^{\mathrm{c}}$ & $0.036^{\mathrm{d}}$ \\
Calcium (\%) & $0.188 \pm$ & $0.243 \pm$ & $0.265 \pm$ & $0.310 \pm$ \\
& $0.003^{\mathrm{a}}$ & $0.005^{\mathrm{b}}$ & $0.003^{\mathrm{c}}$ & $0.005^{\mathrm{d}}$ \\
\hline
\end{tabular}

Mean \pm S.E. with difference superscripts in a row differ significantly $(\mathrm{p}<0.05) ; \mathrm{n}_{1}$ (Product yield) $=5, \mathrm{n}_{2}$ (Physico-chemical parameter) $=10$ for each treatment; T1- Control, T2- Chicken cutlets with 5\% finger millet flour; T3-Chicken cutlets with 10\% finger millet flour, T4- Chicken cutlets with 15\% finger millet flour.

Mean sensory scores of chicken meat cutlets prepared with different levels of finger millet flour are presented in Table 2. There was significant decrease $(p<0.05)$ in appearance and flavor of chicken meat cutlets with increase in finger millet flour level. Decrease in flavour scores might be attributed to development of bitterness due to addition of finger millet flour. The findings are in agreement with those of Sakunde et al. (2007) who also reported a decline in the sensory score for appearance and flavor of chicken patties incorporated with finger millet flour. Texture score at $15 \%$ level of finger millet flour was significantly lower $(p<0.05)$ than control and other treatment products. Decline in texture scores at higher levels of finger millet flour might be due to hardening ofthe product. There was a significant decrease $(p<0.05)$ in the juiciness and overall acceptability of chicken meat cutlets prepared with $10 \%$ and $15 \%$ finger millet flour levels as compared to chicken cutlets with $5 \%$ finger millet flour level as well as control. 
The sensory scores of the chicken cutlets for most of attributes at 5\% level of finger millet flour incorporation were quite comparable with control. Hence, on thebasis of above results, the optimum incorporation level of finger millet flour in chicken meat cutlets was found to be $5 \%$.

Table 2: Effect of different levels of finger millet flour on sensory characteristics of chicken meat cutlets

\begin{tabular}{lllll}
\hline Sensory Attributes & T1 & T2 & T3 & T4 \\
\hline \multirow{2}{*}{ General appearance } & $7.32 \pm$ & $7.26 \pm$ & $6.90 \pm$ & $6.42 \pm$ \\
& $0.11^{\mathrm{c}}$ & $0.11^{\mathrm{c}}$ & $0.12^{\mathrm{b}}$ & $0.13^{\mathrm{a}}$ \\
Flavour & $7.16 \pm$ & $7.19 \pm$ & $6.86 \pm$ & $6.22 \pm$ \\
& $0.09^{\mathrm{c}}$ & $0.09^{\mathrm{c}}$ & $0.09^{\mathrm{b}}$ & $0.12^{\mathrm{a}}$ \\
Texture & $7.20 \pm$ & $7.26 \pm$ & $7.04 \pm$ & $6.40 \pm$ \\
& $0.09^{\mathrm{b}}$ & $0.08^{\mathrm{b}}$ & $0.10^{\mathrm{b}}$ & $0.12^{\mathrm{a}}$ \\
Juiciness & $7.27 \pm$ & $7.10 \pm$ & $6.74 \pm$ & $6.14 \pm$ \\
& $0.08^{\mathrm{c}}$ & $0.13^{\mathrm{c}}$ & $0.11^{\mathrm{b}}$ & $0.12^{\mathrm{a}}$ \\
Overall & $7.39 \pm$ & $7.40 \pm$ & $6.95 \pm$ & $6.24 \pm$ \\
acceptability & $0.06^{\mathrm{c}}$ & $0.07^{\mathrm{c}}$ & $0.08^{\mathrm{b}}$ & $0.10^{\mathrm{a}}$ \\
\hline
\end{tabular}

Mean \pm S.E. with difference superscripts in a row differ significantly $(\mathrm{p}<0.05) ; \mathrm{n}=35$ for each treatment; T1- Control, T2- Chicken cutlets with $5 \%$ finger millet flour; T3- Chicken cutlets with $10 \%$ finger millet flour, T4- Chicken cutlets with 15\% finger millet flour.

The physico-chemical and microbiological characteristics of aerobically packaged chicken meat cutlets during refrigerated storage $\left(4 \pm 1^{\circ} \mathrm{C}\right)$ are presented in Table 3 . The $\mathrm{pH}$ of chicken meat cutlets increased gradually during the entire period of storage and remained comparable up to $6^{\text {th }}$ day of storage. There was a significant increase $(p<0.05)$ in $\mathrm{pH}$ on the $9^{\text {th }}$ day of storage. It might be attributed to the production of basic metabolites and amines due to protein breakdown by microorganism. Free fatty acid values of chicken meat cutlets prepared with 5\% finger millet flour was significantly lower $(\mathrm{p}<0.05)$ as compared to that of control. TBA values of chicken meat cutlets with $5 \%$ finger millet flour was significantly lower $(\mathrm{p}<0.05)$ than control. This might be due to attributed to presence of antioxidants in finger millet flour.

On 0 day of storage, standard plate count of Control (T1) was comparable to chicken meat cutlets with $5 \%$ finger millet flour (T2). On $3^{\text {rd }}$ day of storage SPC of (Control) $\mathrm{T} 1$ was significantly higher $(\mathrm{p}<0.05)$ than $\mathrm{T} 2$. Standard plate count increased significantly $(p<0.05)$ with the advancement of storage period in 5\% finger millet flour (T2) as well as control (T1).
Table 3: Effect of refrigerated storage on physico-chemical and micro-biological characteristics of chicken meat cutlets prepared with optimized level of finger millet flour

\begin{tabular}{|c|c|c|c|c|}
\hline \multirow{2}{*}{ Treatments } & \multicolumn{4}{|c|}{ Refrigerated storage period (Days) } \\
\hline & $\mathbf{0}$ & 3 & 6 & 9 \\
\hline \multicolumn{5}{|c|}{ pH } \\
\hline $\mathrm{T} 1$ & $\begin{array}{l}6.20 \pm \\
0.02^{\mathrm{Aa}}\end{array}$ & $\begin{array}{l}6.25 \pm \\
0.03^{\mathrm{a}}\end{array}$ & $\begin{array}{l}6.31 \pm \\
0.04^{\mathrm{a}}\end{array}$ & $\begin{array}{l}6.52 \pm \\
0.06^{\mathrm{b}}\end{array}$ \\
\hline $\mathrm{T} 2$ & $\begin{array}{l}6.23 \pm \\
0.02^{\mathrm{Aa}}\end{array}$ & $\begin{array}{l}6.27 \pm \\
0.03^{\mathrm{a}}\end{array}$ & $\begin{array}{l}6.32 \pm \\
0.03^{\mathrm{a}}\end{array}$ & $\begin{array}{l}6.53 \pm \\
0.06^{\mathrm{b}}\end{array}$ \\
\hline \multicolumn{5}{|c|}{ FFA Value (\% oleic acid) } \\
\hline $\mathrm{T} 1$ & $\begin{array}{l}0.16 \pm \\
0.008^{\mathrm{Ba}}\end{array}$ & $\begin{array}{l}0.18 \pm \\
0.011^{\mathrm{Ba}}\end{array}$ & $\begin{array}{l}0.20 \pm \\
0.009^{\mathrm{Bab}}\end{array}$ & $\begin{array}{l}0.22 \pm \\
0.017^{\mathrm{Bb}}\end{array}$ \\
\hline $\mathrm{T} 2$ & $\begin{array}{l}0.12 \pm \\
0.008^{\mathrm{Aa}}\end{array}$ & $\begin{array}{l}0.14 \pm \\
0.009^{\text {Aab }}\end{array}$ & $\begin{array}{l}0.15 \pm \\
0.008^{\text {Aab }}\end{array}$ & $\begin{array}{l}0.16 \pm \\
0.000^{\mathrm{Ab}}\end{array}$ \\
\hline \multicolumn{5}{|c|}{ TBARS Value (mg malonaldehyde/Kg) } \\
\hline $\mathrm{T} 1$ & $\begin{array}{l}0.47 \pm \\
0.01^{\mathrm{Ba}}\end{array}$ & $\begin{array}{l}0.52 \pm \\
0.02^{\mathrm{Bab}}\end{array}$ & $\begin{array}{l}0.58 \pm \\
0.02^{\mathrm{b}}\end{array}$ & $\begin{array}{l}0.68 \pm \\
0.02^{\mathrm{c}}\end{array}$ \\
\hline $\mathrm{T} 2$ & $\begin{array}{l}0.21 \pm \\
0.02^{\mathrm{Aa}}\end{array}$ & $\begin{array}{l}0.36 \pm \\
0.02^{\mathrm{Ab}}\end{array}$ & $\begin{array}{l}0.52 \pm \\
0.04^{\mathrm{c}}\end{array}$ & $\begin{array}{l}0.67 \pm \\
0.06^{\mathrm{d}}\end{array}$ \\
\hline \multicolumn{5}{|c|}{ Standard plate count $\left(\log _{10} \mathrm{cfu} / \mathrm{gm}\right)$} \\
\hline $\mathrm{T} 1$ & $\begin{array}{l}1.86 \pm \\
0.07^{\mathrm{Aa}}\end{array}$ & $\begin{array}{l}2.49 \pm \\
0.06^{\mathrm{Bb}}\end{array}$ & $\begin{array}{l}3.64 \pm \\
0.17^{\mathrm{c}}\end{array}$ & $\begin{array}{l}4.86 \pm \\
0.15^{\mathrm{d}}\end{array}$ \\
\hline $\mathrm{T} 2$ & $\begin{array}{l}1.70 \pm \\
0.08^{\mathrm{Aa}}\end{array}$ & $\begin{array}{l}2.23 \pm \\
0.06^{\mathrm{Ab}}\end{array}$ & $\begin{array}{l}3.19 \pm \\
0.23^{\mathrm{c}} \\
\end{array}$ & $\begin{array}{l}4.65 \pm \\
0.21^{\mathrm{d}} \\
\end{array}$ \\
\hline \multicolumn{5}{|c|}{ Psychrophilic counts $\left(\log _{10} \mathrm{cfu} / \mathrm{gm}\right)$} \\
\hline $\mathrm{T} 1$ & ND & ND & $\begin{array}{l}1.57 \pm \\
0.05^{\mathrm{Ba}}\end{array}$ & $\begin{array}{l}2.09 \pm \\
0.06^{\mathrm{b}}\end{array}$ \\
\hline $\mathrm{T} 2$ & ND & ND & $\begin{array}{l}1.11 \pm \\
0.13^{\mathrm{Aa}}\end{array}$ & $\begin{array}{l}1.84 \pm \\
0.09^{\mathrm{b}}\end{array}$ \\
\hline \multicolumn{5}{|c|}{ Yeast and mould count $\left(\log _{10} \mathrm{cfu} / \mathrm{gm}\right)$} \\
\hline $\mathrm{T} 1$ & ND & $\begin{array}{l}1.63 \pm \\
0.03^{\mathrm{Ba}}\end{array}$ & $\begin{array}{l}2.01 \pm \\
0.09^{\mathrm{b}}\end{array}$ & $\begin{array}{l}2.10 \pm \\
0.09^{\mathrm{b}}\end{array}$ \\
\hline $\mathrm{T} 2$ & ND & $\begin{array}{l}1.38 \pm \\
0.08^{\mathrm{Aa}}\end{array}$ & $\begin{array}{l}1.75 \pm \\
0.14^{\mathrm{b}}\end{array}$ & $\begin{array}{l}1.98 \pm \\
0.07^{\mathrm{b}}\end{array}$ \\
\hline \multicolumn{5}{|c|}{ Coliform count $\left(\log _{10} \mathrm{cfu} / \mathrm{gm}\right)$} \\
\hline $\mathrm{T} 1$ & ND & ND & ND & ND \\
\hline $\mathrm{T} 2$ & ND & ND & ND & ND \\
\hline
\end{tabular}

Mean \pm S.E. with difference superscripts in a row (small alphabet) and column (capital alphabet) differ significantly $(\mathrm{p}<0.05) ; \mathrm{n}=10$ for each treatment; ND = Not detected; T1- Control, T2- Chicken cutlets with $5 \%$ finger millet flour.

This increase could be due to the availability of the nutrients and favourable conditions for microbial growth. The findings are in accordance with those of Ahlawat et al. (2012) who also reported increase in total plate count during 
refrigerated storage of chicken cutlets. Psychrophilic microbes were not detected up to $3^{\text {rd }}$ day of refrigerated storage. On $6^{\text {th }}$ day of storage, the psychrophilic counts for chicken meat cutlets with 5\% finger millet flour (T2) was significantly lower than control. Rao and Reddy (2000) also reported significant increase in psychrophilic counts of chicken meat loaves at refrigeration storage. Several studies have demonstrated anti-microbial activity of finger millet against Escherichia coli, Bacillus cereus, Aspergillus niger, etc (Banerjee et al., 2012). High phenolic content of finger millet may inhibit microbial enzymes and oxidation of microbial membranes leading to inhibitory activities of proliferation of bacterial cells. Coliforms were not detected in during entire period of storage. This might be due to the good hygienic practices during the processing of products. Similarly, Sachdev and Gopal (2000) observed no coliforms during refrigeration storage of cooked chicken rolls.

Table 4: Effect of refrigerated storage on sensory characteristics of chicken meat cutlets prepared with optimized level of finger millet flour

\begin{tabular}{|c|c|c|c|c|}
\hline \multirow{2}{*}{ Treatment } & \multicolumn{4}{|c|}{ Refrigerated storage period (Days) } \\
\hline & $\mathbf{0}$ & 3 & 6 & 9 \\
\hline \multicolumn{5}{|c|}{ General appearance } \\
\hline $\mathrm{T} 1$ & $7.27 \pm 0.08^{\mathrm{c}}$ & $7.02 \pm 0.06^{\mathrm{b}}$ & $6.76 \pm 0.07^{\mathrm{a}}$ & ND \\
\hline $\mathrm{T} 2$ & $7.19 \pm 0.07^{\mathrm{c}}$ & $6.84 \pm 0.10^{\mathrm{b}}$ & $6.57 \pm 0.09^{\mathrm{a}}$ & ND \\
\hline \multicolumn{5}{|c|}{ Flavour } \\
\hline $\mathrm{T} 1$ & $7.24 \pm 0.08^{\mathrm{cA}}$ & $6.92 \pm 0.08^{\mathrm{ABb}}$ & $6.50 \pm 0.08^{\mathrm{a}}$ & ND \\
\hline $\mathrm{T} 2$ & $7.11 \pm 0.09^{\mathrm{cA}}$ & $6.67 \pm 0.10^{\mathrm{Ab}}$ & $6.24 \pm 0.09^{\mathrm{a}}$ & ND \\
\hline \multicolumn{5}{|c|}{ Texture } \\
\hline $\mathrm{T} 1$ & $7.15 \pm 0.09^{c}$ & $6.81 \pm 0.08^{b}$ & $6.42 \pm 0.10^{\mathrm{a}}$ & ND \\
\hline $\mathrm{T} 2$ & $7.15 \pm 0.09^{c}$ & $6.74 \pm 0.11^{\mathrm{b}}$ & $6.24 \pm 0.11^{\mathrm{a}}$ & ND \\
\hline \multicolumn{5}{|c|}{ Juiciness } \\
\hline $\mathrm{T} 1$ & $7.16 \pm 0.09^{\mathrm{cA}}$ & $6.70 \pm 0.10^{\mathrm{bB}}$ & $6.27 \pm 0.10^{\mathrm{a}}$ & ND \\
\hline $\mathrm{T} 2$ & $6.99 \pm 0.10^{\mathrm{bA}}$ & $6.39 \pm 0.13^{\mathrm{aA}}$ & $6.06 \pm 0.12^{\mathrm{a}}$ & ND \\
\hline \multicolumn{5}{|c|}{ Overall acceptability } \\
\hline $\mathrm{T} 1$ & $7.20 \pm 0.09^{\mathrm{cA}}$ & $6.88 \pm 0.08^{\mathrm{b}}$ & $6.42 \pm 0.07^{\mathrm{a}}$ & ND \\
\hline $\mathrm{T} 2$ & $7.03 \pm 0.09^{\mathrm{cA}}$ & $6.65 \pm 0.10^{\mathrm{b}}$ & $6.17 \pm 0.09^{a}$ & ND \\
\hline
\end{tabular}

Mean \pm S.E. with difference superscripts in a row (small alphabet) and column (capital alphabet) differ significantly $(\mathrm{p}<0.05) ; \mathrm{n}=35$ for each treatment; ND=Not detected; T1- Control. T2- Chicken cutlets with $5 \%$ finger millet flour

On 0 day of storage, there was no growth of yeast and moulds in control (T1) and chicken meat cutlets prepared with 5\% finger millet flour (T2). However, on $3^{\text {rd }}$ day of storage, growth of yeasts and moulds were observed in T1 and T2. Yeast and mould count of chicken meat cutlets prepared with 5\% finger millet flour (T2) was significantly $(p<0.05)$ lower than control (T1). This might be due to anti-microbial activity of finger millet phenolics. Yeast and mould counts of chicken cutlets on $6^{\text {th }}$ day of storage were comparable to $9^{\text {th }}$ day of storage. Das et al. (2013) also reported significant increase in yeast and mould counts of chicken nuggets during refrigerated storage.

The sensory characteristics of aerobically packaged chicken meat cutlets during refrigerated storage $\left(4 \pm 1^{\circ} \mathrm{C}\right)$ are presented in Table 4. There was a significant decrease $(p<0.01)$ in flavor, texture, juiciness and overall acceptability scores of the products during storage period. The progressive decrease in flavour scores could be correlated to an increase in TBA value and free fatty acids and gradual loss of moisture in the chicken meat cutlets. Similar findings were also reported by Ahamed et al. (2007) and Pathak et al. (2009).

\section{CONCLUSION}

The present study showed that the optimum level of finger millet flour was 5\% for incorporation in chicken meat cutlets and it could be stored safely in aerobic packaging for 6 days at refrigeration condition $\left(4 \pm 1^{\circ} \mathrm{C}\right)$.

\section{REFERENCES}

Ahamed, M.E., Anjaneyulu, A.S.R., Sathu, T., Thomas, R. and Kondaiah, N. 2007. Effect of different binders on the quality of enrobed buffalo meat cutlets and their shelf life at refrigeration storage $\left(4 \pm 1{ }^{\circ} \mathrm{C}\right)$. Meat Sci., 75(3): 451-459.

Ahlawat, S.S., Sharma, D.P. and Khanna, N. 2012. Development of low cost chicken cutlets using different extenders. J. Dairy Foods Home Sci., 31(3): 199-202.

AOAC. 1995. Official Method of Analysis. $16^{\text {th }}$ edition. Association of Official Analytical Chemists, Washington, DC.

APHA. 2001. Compendium of methods for the microbiological examination of foods. $4^{\text {th }}$ edition. American Public Health Association Washington, DC.

Banerjee, S., Sanjay, K., Chethan, S. and Malleshi, N.G. 2012. Finger millet (Eleusine coracana) polyphenols: Investigation of their antioxidant capacity and antimicrobial activity. Afr. $J$. Food Sci., 6: 362-374. 
Bhat, Z.F., Pathak, V. and Bhat, H.F. 2013. Effect of refrigerated storage onthe quality characteristics of microwave cooked chicken seekh kababs extended with different non-meat proteins. ¡J. Food Sci. Technol., 50: 926-933.

Chandralekha, S., Babu, A.J., Moorthy, P.S. and Karthikeyan, B. 2012. Studies on the effect of pomegranate rind powder extract as natural antioxidant in chicken meat balls during refrigerated storage. J. Adv. Vet. Res., 2(2): 107-112.

Chatli, M.K., Kumar, P., Mehta, N., Verma, A.K., Kumar, D. and Malav, O.P. 2015. Quality characteristics and storage stability of emu meatnuggets formulated with finger millet (Eleusine coracana) flour. Nutr Food Sci., 45(5): 740-752.

Das, A.K., Anjeneyulu, A.S.R., Verma, A.K. and Kondaiah, N. 2006. Physico-chemical, textural, sensory characteristics and storage stabilityof goat meat patties extended with full fat soy paste and soy granules. Int. J. Food Sci. Technol., 49: 547-553.

Das, A., Nath, D.R., Kumari, S. and Saha, R. 2013. Effect of fermented bambooshoot on the quality and shelf life of nuggets prepared from desi spent hen. Vet. World, 6: 419-423.

Das, S.K., Prabhakaran, P., Tanwar, V.K. and Biswas, S. 2015. Effect of someplant starches and carrageenan as fat substitutes in chicken patties. J. Anim. Sci., 93(7): 3704-3712.

Gupta, S., Sharma, B.D. and Mendiratta, S.K. 2015. Evaluation of quality characteristics of restructured spent hen meat blocks incorporated with oat meal. Nutr. Food Sci., 45(5): 774-782.

Keeton, J.T. 1983. Effect of fat and $\mathrm{NaCl} /$ phosphate levels on the chemical and sensory properties of pork patties. J. Food Sci., 48: 878-881.

Koniecko, E.K. 1979. Handbook for meat chemists. Wayne, New Jersey, USA:Avery Publishing Group Inc, pp. 68-69.

Kumar, Y., Shuklaa, P., Singha, P., Tanwara, V.K., Thorib, M. K. and Sharmac, V. 2015. Effect of dried carrot powder incorporation on quality attributes of chicken cutlets. $J$. Ready Eat Food., 2(3):89-95.
Naveena, B.M., Muthukumar, M., Sen, A.R., Babji, Y. and Murthy, T.R.K. 2006. Quality characteristics and storage stability of chicken patties formulated with finger millet flour (Eleusine coracana). J. Muscle Foods, 17(1): 92-104.

Pathak, V., Bhat, Z.F., Bukhari, S.A.A. and Ahmad, S.R. 2009. Effect of different levels of porridge on the quality characteristics of chicken patties. Indian J. Poult. Sci., 44(1): 87-90.

Rao, B.J. and Reddy, K.P. 2000. Influence of binders and refrigerated storage on the quality of chicken meat loaves. Indian J. Poult. Sci., 35: 302-305.

Sachdev, A.K. and Gopal, R. 2000. Storage quality changes in cooked chicken rolls. Indian J. Poult. Sci., 35: 364-366.

Sakunde, D.T., Ambadkar, R.K., Zanjad, P.N. and Naveena, B.M. 2007. Effect of addition of ragi flour on the quality of chicken patties. J. Bombay Vet. Coll., 15(1\&2): 84-87.

Singh, P. and Raghuvanshi, R.S. 2012. Finger millet for food and nutritional security. Afr J. Food Sci., 6(4): 77-84.

Singh, P.K., Kumar, S., Kumar, P. and Bhat, Z.F. 2014. Effect of mincing on the quality characteristics of chevon cutlets. $J$. Anim. Res., 4(2): 193-200.

Snedecor, G.W. and Cochran, W.G. 1994. Statistical Methods. $8^{\text {th }}$ Edn, Iowa State University Press, Ames, Iowa.

Trout, E.S., Hunt, M.C., Johnson, D.E., Claus, J.R., Kastner, C. L. and Kropf, D.H. 1992. Characteristics of low fat ground beef containing texture modifying ingredients. J. Food Sci., 57: 19-24.

Viswanath, V., Urooj, A. and Malleshi, N.G. 2009. Evaluation of antioxidant and antimicrobial properties of finger millet polyphenols (Eleusine coracana). Food Chem., 114(1): 340346.

Witte, V.C., Krause, G.F. and Bailey, M.E. 1970. Anew extraction method for determining 2-thiobarbituric acid values of pork and beef during storage. J. Food Sci., 35: 582-585. 